\title{
Antibody elution from red blood cells
}

\author{
HARRY RUBIN ${ }^{1}$ \\ From the Department of Haematology, Postgraduate Medical School of London
}

SYNOPSIS An elution technique is described which gives eluates at least as potent as previously $\underset{\vec{\omega}}{\grave{\omega}}$ described methods. Elution can be completed in only 15 minutes. The method, a modification of that of Vos and Kelsall, is simple to carry out and requires the minimum of equipment. Studies? have shown that the coating antibody is almost, but not completely, eluted.

Antibody protein adherent to the red cell surface can be detected in several ways. However, in order to determine their serological specificity it is necessary to elute them so that they can then be tested with red cells of known antigenic content. A number of methods have been devised to elute the antibodies but each method suffers from one of two faults; either weak eluates are obtained or potent eluates are obtained only after several hours' or days' work. A rapid simple procedure yielding high-titred eluates would be of considerable practical value.

By far the simplest procedure for elution is the original method of Landsteiner and Miller (1925). Although requiring only 10 to 15 minutes to carry out, this method, unfortunately, gives eluates which are low in antibody activity. Other and later methods are more elaborate and time-consuming, entailing first separating red blood cell stroma from haemoglobin as completely as possible which adds significantly to the time involved in the procedure, and then eluting the antibody from the stroma. Kidd (1949) eluted antibodies by exposing stroma to a buffer at $p \mathrm{H} 3.2$ to 3.4 at room temperature but this method is complicated. Selwyn (1952) prepared stroma in the same way but then eluted the antibody by heating the stroma to $60^{\circ} \mathrm{C}$. at a $p \mathrm{H}$ of 6.6 to $6 \cdot 8$. Mitchell (1956) attempted to define the optimum conditions of temperature and $p \mathrm{H}$ at which antibodies are best eluted and found that for different types of antibodies, different optima applied. He also stated that the texture of the initial stromal precipitate affected the yield of antibody. His method as finally evolved requires two dialysis steps and 48 hours before the final eluate was obtained.

Weiner (1957) precipitated stroma and antibody in cold $50 \%$ ethanol and then eluted at $37^{\circ} \mathrm{C}$. The

${ }^{1}$ Trainee, National Institute of Arthritis and Metabolic Diseases, National Institutes of Health, Bethesda, Maryland.

Received for publication 11 July 1962. method requires about three hours but with some $ᄋ$ minor modifications (Jensen, 1959) it can be accom- plished in about one and a half hours without reducing the antibody content significantly. Komninos and Rosenthal (1953) suspended red-cell stroma in $8 \%$ hypertonic sodium chloride at room $\_$ temperature and obtained good eluates. An addi- $\mathscr{C}$ tional 48 hours was required, however, to bring the $\omega$ eluate to isotonicity by dialysis before it could be tested.

Greenwalt (1956) precipitated stroma in cold $0.25 \%$ formalin and then separated the stroma on glass wool. Elution is accomplished at $56^{\circ} \mathrm{C}$. This $\stackrel{\varnothing}{\varnothing}$ takes somewhat more than two hours to perform. $\stackrel{2}{\vec{F}}$ Vos and Kelsall (1956) treated acid-precipitated $\frac{3}{3}$ stroma with diethyl ether and obtained very good eluates in about one and a half to two hours.

The purpose of the present study was to compare some of the less time-consuming methods of anti-? body elution and if possible to improve on them. It $\frac{0}{3}$ was found that the methods of Weiner and Vos and. of Kelsall gave the strongest eluates and by modify-을 ing the latter method eluates have been obtained as strong as those obtained by the original method? although the working time has been reduced to $15 \mathrm{D}$ minutes. The modified method is described. In addition some observations on the sensitized cells of patients with auto-immune haemolytic anaemia are reported.

\section{METHODS}

GENERAL The general techniques applied in this study were those previously described by Dacie (1956). Com parisons between methods were always begun on the same day. When sensitizing cells with antibody, the same source of fresh red cells or cells stored in acid-citrate-喏 dextrose solution for not more than one week was used $\stackrel{?}{+}$ In the initial studies an incomplete warm type of anti-DQ was used as a prototype antibody. 
TECHNIQUE OF ELUTION An equal volume of $0.85 \%$ saline is added to one volume of washed and packed red cells. To this mixture is then added two volumes of diethyl ether A.R. The container is stoppered and mixed by repeated inversions for one minute. Mixing for longer periods does not influence the strength of the final eluate (Table I). The mixture is then centrifuged for 10 minutes at 3,000 r.p.m. After centrifugation three clearly defined layers are visible: an upper layer of ether, a middle layer of denatured stroma, and a bottom layer of haemoglobinstained fluid. The two top layers are removed by vacuum suction and the haemoglobin-stained fluid remaining is the eluate. This can be tested immediately or stored frozen at $-20^{\circ} \mathrm{C}$. In the latter instance, the eluate should first be placed in a $37^{\circ} \mathrm{C}$. water-bath for 15 minutes to evaporate any residual ether. Eluates prepared in this way have been stored frozen at $-20^{\circ} \mathrm{C}$. for three months without any loss of antibody activity. Vos and Kelsall reported that their eluates kept at $-20^{\circ} \mathrm{C}$. for two years without any significant change in antibody titre. They, however, employed type AB serum instead of saline as an eluting media and this may influence the potency of the eluates after storage.

The method can be applied successfully to fresh red cells or to cells stored frozen after washing and packing without the addition of any preservative solutions. The haemoglobin in the eluate, although aesthetically unpleasing, does not interfere with the reading of agglutination when its antibody content is titrated with enzyme-treated cells and it is irrelevant when using the indirect antiglobin technique.

SENSITIZATION INDEX An attempt was made to relate the antibody content of the final eluates with the degree of sensitization of the original red cells in order to determine to what extent elution was quantitative. The same rabbit antihuman globulin reagent (Universal antihuman globulin) prepared in this laboratory was used throughout. The degree of sensitization of the red cells has been scored by taking into account the intensity of agglutination (0 to $4+)$ and the dilution of the antiglobulin serum producing agglutination. The agglutination score was obtained by adding together the number of plus signs at each dilution of antiglobulin serum and multiplying by the number of dilutions in which agglutination occurred. The time at which agglutination occurs after adding the reagent is also a reflection of the amount of antibody coating the cell. An arbitrary index of sensitization was therefore calculated as follows:-

$$
\text { Sensitization index }=\frac{\text { agglutination score }}{\text { time of agglutination (in seconds) }}
$$

The dilution of the antiglobulin reagent at which the agglutination was timed was one which gave strong agglutination in all instances, 1 in 64 . The average of two readings was used and the time was reproducible within one or two seconds (naked-eye reading).

\section{TABLE I}

COMPARISON BETWEEN SHAKING TIME AND STRENGTH OF ELUATES FOR BOTH WEAKLY AND STRONGLY SENSITIZED CELLS

Shaking Time in Minutes Dilution of Eluates

\begin{tabular}{|c|c|c|c|c|c|c|c|}
\hline & \\
\hline & 1 in 1 & 1 in 2 & 1 in 4 & 1 in 8 & 1 in 16 & 1 in 32 & Saline Control \\
\hline \multicolumn{8}{|c|}{ Weakly sensitized cells } \\
\hline 1 & + & 0 & 0 & 0 & 0 & 0 & 0 \\
\hline 5 & + & $\mathbf{0}$ & $\mathbf{0}$ & $\mathbf{0}$ & 0 & 0 & 0 \\
\hline 15 & + & $( \pm)$ & $\mathbf{0}$ & 0 & 0 & 0 & 0 \\
\hline \multicolumn{8}{|c|}{ Strongly sensitized cells } \\
\hline 1 & ++ & ++ & $+( \pm)$ & + & $( \pm)$ & 0 & $\mathbf{0}$ \\
\hline 5 & ++ & ++ & + & + & $( \pm)$ & 0 & $\mathbf{0}$ \\
\hline 15 & $+t$ & $+t$ & $+( \pm)$ & + & $( \pm)$ & $\mathbf{0}$ & $\mathbf{0}$ \\
\hline
\end{tabular}

TABLE II

COMPARISON OF ELUTION METHODS

\begin{tabular}{|c|c|c|c|c|c|c|c|c|c|c|}
\hline \multirow{3}{*}{$\begin{array}{l}\text { Method of } \\
\text { Elution }\end{array}$} & \multicolumn{8}{|c|}{ 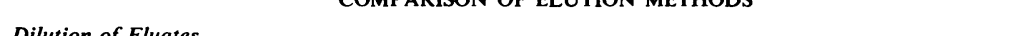 } & \multirow{3}{*}{$\begin{array}{l}\text { Saline } \\
\text { Control }\end{array}$} & \multirow{3}{*}{$\begin{array}{l}\text { Agglu- } \\
\text { tination } \\
\text { Score }\end{array}$} \\
\hline & Dilution of & luates & & & & & & & & \\
\hline & 1 in 1 & 1 in 2 & 1 in 4 & 1 in 8 & 1 in 16 & 1 in 32 & 1 in 64 & 1 in 128 & & \\
\hline \multicolumn{11}{|c|}{ Titration of eluates of anti-D with trypsinized cells at $37^{\circ} \mathrm{C}$. } \\
\hline Greenwalt & ++ & $+( \pm)$ & + & $\div$ & $( \pm)$ & $( \pm)$ & $\mathbf{0}$ & $\mathbf{0}$ & $\mathbf{0}$ & 39 \\
\hline Landsteiner & +++ & +++ & $++( \pm)$ & ++ & & + & $( \pm)$ & & $\mathbf{0}$ & 91 \\
\hline Weiner & $t++( \pm)$ & +++ & $++t$ & $++( \pm)$ & $+( \pm)$ & + & + & $( \pm)$ & 0 & 128 \\
\hline Vos and Kelsall & $++t+$ & $+t+t$ & ++++ & $+t+( \pm)$ & $++t$ & ++ & + & $( \pm)$ & $\mathbf{0}$ & 176 \\
\hline Present method & +++ & +++ & ++++ & +++ & $+t+( \pm)$ & $++( \pm)$ & + & $( \pm)$ & $\mathbf{0}$ & 188 \\
\hline \multicolumn{11}{|c|}{ Titration of eluates of anti- $D$ by indirect antiglobulin method } \\
\hline Greenwalt & $++( \pm)$ & ++ & + & $( \pm)$ & $\mathbf{0}$ & 0 & $\mathbf{0}$ & 0 & $\mathbf{0}$ & 24 \\
\hline Landsteiner & +++ & $+t+$ & +++ & ++ & ++ & + & $\mathbf{0}$ & 0 & $\mathbf{0}$ & 84 \\
\hline Weiner & $+t+t$ & $+++( \pm)$ & +++ & +++ & $++( \pm)$ & ++ & $\rightarrow$ & 0 & 0 & 133 \\
\hline Vos and Kelsall & $++t$ & $t+t( \pm)$ & $+t+$ & $+t+$ & $++( \pm)$ & ++ & $+\div$ & + & 0 & 168 \\
\hline Present method & +++ & $+++( \pm)$ & $++t$ & ++ & ++ & $+( \pm)$ & + & + & $\mathbf{0}$ & 152 \\
\hline
\end{tabular}


RESULTS

COMPARISON OF METHODS In attempting to develop a practical elution technique, a comparison was made between some of the simpler and less timeconsuming methods previously described (Table II). It is evident that both Weiner's and Vos and Kelsall's methods give the strongest eluates. It can also be seen that the present modification of Vos and Kelsall's method results in eluates of potency at least equal to that of the original procedure. Minor variations in comparing the agglutination scores of the eluate titrations using the indirect antiglobulin method or trypsinized cells are within the limits of error of these methods. The important point is that repeated comparisons showed that Vos and Kelsall's and the present method yielded the highest titred eluates of approximately the same potency.

COMPLETENESS OF ELUTION Thoroughly washed group $\mathrm{O}, \mathrm{Rh}$-positive red cells were sensitized by an anti-D serum diluted in two-fold steps up to 1 in 16 . Each of five batches of cells was exposed to two volumes of the five serum dilutions for two hours at $37^{\circ} \mathrm{C}$. They were then washed four times in a large volume of isotonic saline and a sensitization index for each batch of cells was calculated using the antiglobulin method (Table III). Then equal volumes of packed sensitized cells were eluted with ether as

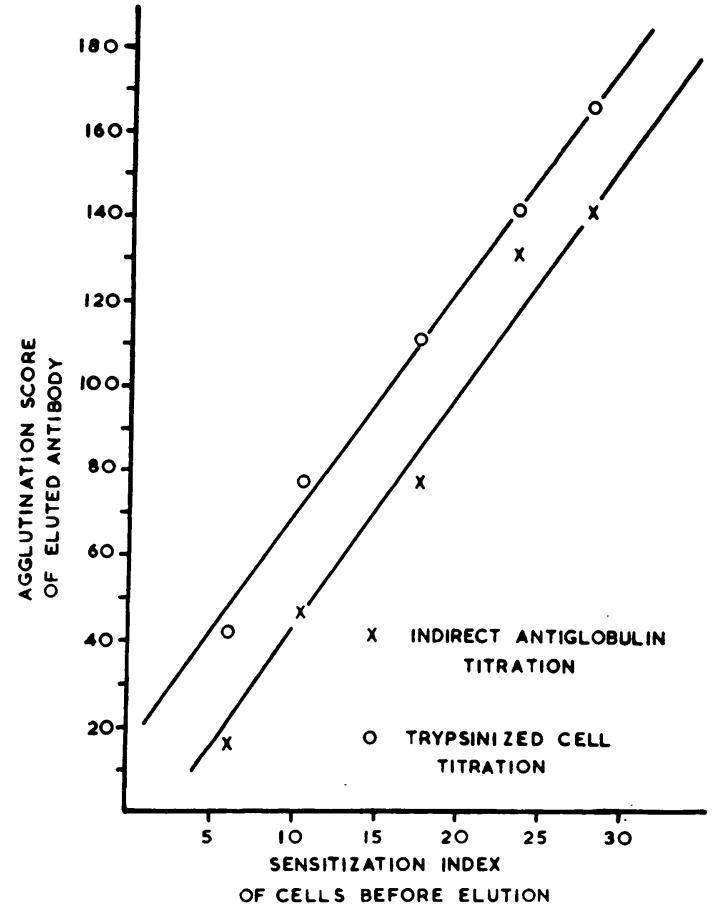

FIG. 1. Relationship of sensitization index to agglutination score of eluted antibody.

TABLE III

RELATIONSHIP OF SENSITIZATION INDEX TO AGGLUTINATION SCORE OF ELUATES OF ANTI-D

\begin{tabular}{cccc} 
Dilution of Anti-D Serum & Sensitization Index & $\begin{array}{c}\text { Agglutination Score of Eluate by } \\
\text { Indirect Antiglobulin Method }\end{array}$ & $\begin{array}{c}\text { Agglutination Score of Eluate with } \\
\text { Trypsinized Cells at 37 C. }\end{array}$ \\
\hline Undiluted & $28 \cdot 0$ & 143 \\
1 in 2 & $23 \cdot 5$ & 133 \\
1 in 4 & $17 \cdot 6$ & 78 & 168 \\
1 in 8 & $10 \cdot 3$ & 143 & 112 \\
1 in 16 & $5 \cdot 9$ & 48
\end{tabular}

TABLE IV

RESULTS OF ELUTION WITH SENSITIZED CELLS FROM PATIENTS WITH AUTO-IMMUNE HAEMOLYTIC ANAEMIA

\begin{tabular}{llll} 
Patient & Diagnosis & Type Antibody & State of Red Blood Cells \\
\hline P.D. & Disseminated lupus erythematosus & Mixed $\gamma$ and non- $\gamma$ & Fresh \\
B.B. & Disseminated lupus erythematosus & Mixed $\gamma$ and non- $\gamma$ & Stored \\
E.B. & Chronic lymphocytic leukaemia & Warm, & Fresh \\
R.D. & Idiopathic auto-immune haemolytic anaemia & Warm, $\gamma$ & Fresh \\
K.W. & Idiopathic auto-immune haemolytic anaemia & Warm, $\gamma$ & Fresh \\
L.F. & Idiopathic auto-immune haemolytic anaemia & Warm, $\gamma$ & Fresh \\
B.H. & Idiopathic auto-immune haemolytic anaemia & Warm, $\gamma$ & Fresh \\
G.N. & Idiopathic auto-immune haemolytic anaemia & Warm, $\gamma$ & Stored \\
F.A. & Idiopathic auto-immune haemolytic anaemia & Warm, $\gamma$ & Stored \\
A.H. & Idiopathic auto-immune haemolytic anaemia & Warm, $\gamma$ & Stored \\
E.N. & Idiopathic auto-immune haemolytic anaemia & Warm, $\gamma$ & Fresh \\
E.P. & Idiopathic auto-immune haemolytic anaemia & Warm, $\gamma$ & Fresh
\end{tabular}


described. The resulting eluates were then rated against trypsinized cells and also by the indirect antiglobulin method and the agglutination score for each eluate was calculated (Table III). Figure 1 shows that the relationship between the sensitization indices and the agglutination scores of the eluates is linear. This implies a quantitative relationship but not necessarily that elution approaches completeness.

When the denatured stroma obtained after the first elution was saved, thoroughly washed in saline and a second elution with ether performed, the secondary eluate contained little antibody. This finding was consistent and independent of the degree of sensitization of the original cells or the time of mixing during the first elution. It seems, therefore, that although elution is not absolutely complete, it very nearly approaches completeness.

TYPE OF ANTIBODIES ELUTED Many different samples of incomplete anti-D were successfully eluted from Rh-positive cells after sensitization. Whether the present method of elution can be applied to antibodies of other types still requires elucidation.

AUTO-IMMUNE HAEMOLYTIC ANAEMIA The red cells of 12 patients with auto-immune haemolytic anaemias were tested by this method; 10 gave potent eluates (Table IV). All of these patients had warmtype antibodies giving gamma type reactions in the direct antiglobulin test, including the two patients whose eluates did not apparently contain any antibody. Attempts at elution using all of the previously mentioned elution methods were equally unsuccessful with the sensitized red cells of these two patients. The lack of success with these two patients is unexplained.

The red cells tested were freshly obtained except for four patients whose cells had been stored frozen for up to two years (Table IV).

\section{REFERENCES}

Dacie, J. V. (1956). Practical Haematology, 2nd ed. Churchill, London.

Greenwalt, T. J. (1956). J. Lab. clin. Med., 48, 634.

Jensen, K. G. (1959). Vox Sang. (Basel), n.s. 4, 230.

Kidd, P. (1949). J. clin. Path., 2, 103.

Komninos, Z. D., and Rosenthal, M. C. (1953). J. Lab. clin. Med., $41,887$.

Landsteiner, K., and Miller, C. P. (1925). J. exp. Med., 42, 853.

Mitchell, J. C. (1956). University thesis (Aberdeen).

Selwyn, J. G. (1952). University thesis (Cambridge).

Vos, G. H., and Kelsall, G. A. (1956). Brit. J. Haemat., 2, 342.

Weiner, W. (1957). Ibid., 3, 276. 